\title{
Sustainability Related Issues Among Construction Students: Analyzing Through Source of Knowledge, Education Preparation and Future Aspiration
}

\author{
Sanjeev Adhikari, Ph.D. and Kathryn \\ Bedette, AIA \\ Kennesaw State University \\ Marietta, GA
}

\author{
Rui Zhang and Caroline $M$. \\ Clevenger, Ph.D. \\ University of Colorado Denver \\ Denver, CO
}

The purpose of this research is to analyze the perception of sustainability-related issues among construction students. The perceived importance of sustainable construction is analyzed based on students' source of knowledge, university education, and future aspirations toward sustainability goals. This study involved conducting surveys from construction management students to determine their perception of the following eight options: environmental sustainability, societal sustainability, economic sustainability, energy sustainability, water sustainability, material choice sustainability, zero-emission sustainability, and lean zero-waste sustainability. The survey aimed to explore construction students' perception of sustainable design and construction, and what role education plays in this perception. To support these aims, survey evaluation includes both quantitative and qualitative data analysis. Students are best equipped to explain their understanding of the listed options, based on their individual experiences. The results show that most students think water sustainability, environmental sustainability, and energy sustainability are "extremely important". In addition to providing insight into students' perception of the relative importance of these sustainability approaches, analysis of the survey responses offers key findings on the source of students' sustainability knowledge, the degree to which students have made decisions about their career paths, and the potential relationship between knowledge gained and students' perception of the impact of sustainable design and construction options. Analysis of these perceptions is a crucial tool for educators in improving students' understanding of sustainability goals.

Key Words: Sustainability, Construction Education, Sustainable Design and Construction, Student Learning

\section{Introduction}

Sustainable design and construction is the practice of creating structures using environmentally responsible and resource-efficient processes that affect the life cycle of a building (Ahn et. al 2013). As the population grows, energy use will increase by $44 \%$ by 2030 (Iyer-Raniga, 2010, 2012). According to Iyer-Raniga $(2010,2012)$, approximately $40-50 \%$ of the energy used per year in the world is consumed by the construction industry. This energy consumption results from the 
manufacture of construction materials and from the construction process itself. Various construction activities, such as the design, construction, facility management, renovation, and demolition of buildings, directly or indirectly affect the environmental performance of the construction sector (Boardman, 2004). It is known that the construction industry falls behind other industries in terms of progress in sustainability and acceptance of environmental practices. As a result, the construction industry needs to find ways to stop and reverse its contribution to the annual increase in energy demand (Iyer-Raniga, 2010, 2012).

There is still a lot of room for improvement to reduce the environmental impact of the construction sector (Boardman, 2004). As a part of global efforts to protect the environment and respond to climate change, 'green buildings' have been developed to reduce or eliminate the negative impacts of the construction sector and to have a positive impact on our climate and natural environment (World Green Building Council, 2017). Today's students will make decisions in the field tomorrow. To fully address the sustainability gaps in construction activities, we must better understand the role education plays in students' perception of sustainable design and construction approaches and their impact. Toward this end, this study involved determining construction management students' perception of sustainable design and construction options such as environmental sustainability, societal sustainability, economic sustainability, energy sustainability, water sustainability, material choice sustainability, zero-emission sustainability, and lean zero-waste sustainability. Results with this pool of participants suggest that higher education plays a key role in the formation of the perceptions recorded.

\section{Background}

The term "sustainability" has been widely used in the fields of construction and urban planning (Hassanpour, 2017) and it is not just a short-term goal but is a long-term, industry-wide project which can help humans to have a better quality of life. Sustainability is considered in the relationship between people, buildings, and the environment and the impact of buildings on the environment (NAAB, 2012). The sustainability of buildings is the result of construction and construction activities that can help people and the environment and there are many possible sustainable development measures in building construction (Wang, 2009). Sustainability in construction includes both design and materials. Recycling, reducing waste, minimizing negative and maximizing positive impacts are the goals for sustainable design.

Education for sustainable development is an important part of the journey of sustainable life and work and deals with environmental changes that have occurred (Iyer-Raniga, 2012). On the other hand, education enables students to think and act independently and understand the application of knowledge. In recent years, many professional organizations have agreed on the need to incorporate sustainability into engineering education and this need has been widely recognized. Reflecting the concept of sustainability in the course content and providing sufficient sustainability education standards are also issues that need to be considered. Some higher education institutions have added sustainability courses to their construction curricula and made them compulsory courses for students. But there is a challenge in sustainable design education, which is to recognize the need for change and apply it to the enterprise (Hassanpour, 2017). Therefore, the need still exists to discover an appropriate way to improve sustainability education. Appropriate engineering activities and education can enable students to increase their understanding of the world and their commitment to sustainable development (WEFO, 2006). On the other hand, while sustainability education equips future engineers with sustainable thinking and knowledge, findings also show that it promotes international 
cooperation between universities as they seek a common academic framework on sustainability education (Wang, 2009).

Tinkler and Burt (2004) surveyed universities on the assessment of environmentally related construction courses. According to Tinkler and Burt (2004), some universities are offering either individual courses or incorporating green ideas into the curriculum, and since there is a growing trend in sustainable construction, more education is needed on sustainable construction issues. According to Wei and Luo (2016), construction and engineering education is facing challenges in meeting the emerging trend of integrated BIM and sustainable design and construction practices to align with Student Learning Outcomes (SLO)(Wei and Luo 2016). Humphries-Smith (2008) explores curriculum design on the issue of sustainable design. In their study (Humphries-Smith 2008), they recommended explicitly incorporating the sustainable title of some courses.

Students should be able to understand and explain the sustainable features in the design. Education will strengthen students' understanding of sustainability and help them develop a positive attitude towards sustainability. It can also help students to have a deeper understanding of sustainability issues and the ability to think critically. Sustainability education outcomes include both "understanding" and "ability" for students, meaning that students not only need to be aware of sustainability issues but also need to have skills that enable them to cope with rapidly changing industries (Iyer-Raniga, 2012). Further, the ability in construction professionals to create or design sustainable buildings is closely related to the skills, knowledge, and ability students acquire in the subject during the education process (Yüksek, 2013). From education, students can have a broader understanding of sustainable development and have a deeper connection with sustainable development (NAAB, 2012). On the other hand, there is a growing movement to transform our educational system to better prepare students to live in and address this changing world (Haines, 2010).

This study helps to analyze construction students' knowledge of sustainable design and construction and what role education plays in the perception towards sustainable construction. To support these aims, the survey is evaluated through both quantitative and qualitative data analysis. The methodology section details the data analysis of the survey. The final section presents the results and the conclusion of this research.

\section{Methodology}

The study used a survey method to determine student experience with important issues related to sustainability, examine source(s) of knowledge, and evaluate sustainability preparation obtained through university education. The most relevant questions asked of students are: 1) demography data self-identify race and enrolled year; 2) construction work experience; 3) rate the importance of sustainability issues; 4) rank the future impact of sustainability issues; 5) identify sources of sustainability knowledge; 6) education preparation; 7) construction courses with sustainability content; 8) aspiration of continuing to pursue sustainability after graduation. The survey was conducted online as it allowed researchers to identify the student's current experiences and knowledge at the point in time. Also, the online survey was selected because the method allowed documentation of responses at a faster rate in comparison to other survey methods. Qualtrics software was used as the platform for the data collection. The survey consisted of multiple-choice, Likert scale, and slider scale questions. The survey questions were designed in such a manner that the respondents could complete the survey within 6 minutes. The population for the study was students enrolled in construction management courses at a University located in Georgia. 


\section{Data Analysis and Results}

The survey had 72 participants of 80 invited for participation. Of the 72 responding students, four were Civil Engineering majors, 67 were Construction Management majors and one was from another major. The majority of students (62 students) were male $(87.32 \%)$ and nine $(12.68 \%)$ students were female. Over half of the students self-identified as Caucasian (46 or 64.79\%), seven (9.86\%) students identified as African American, nine (12.68\%) identified as Hispanic. Also, two (2.82\%) students self-identified as two races, five (7.04\%) students indicated a preference, not to state, and two $(2.82 \%)$ identified as "other". The majority of students were undergraduates (68 or $95.78 \%$ ), and three (4\%) participants were graduate students. At the time of participation, three-quarters of the students, or 53 students, $(74.65 \%)$ had work experience. None of them had worked for more than ten years and most of them worked between 1-4 years (44 students or $61.97 \%)$. In addition to this, nine $(12.68 \%)$ students worked between 5-10 years, and 18 (25.35\%) of them had no work experience. The demographic data of majors, gender, race, and construction work are summarized in Table 1.

Table 1: Demographics Data of Student Respondent

\begin{tabular}{|l|r|l|r|}
\hline Construction Major & $94.40 \%$ & Non-Minority & $34.70 \%$ \\
\hline Non-Construction Major & $6.90 \%$ & Graduate Students & $4.20 \%$ \\
\hline Male & $87.50 \%$ & Undergraduate Students & $95.80 \%$ \\
\hline Female & $12.50 \%$ & Have Work Experience & $75 \%$ \\
\hline Minority & $65.30 \%$ & No Work Experience & $25 \%$ \\
\hline
\end{tabular}

(72 Responded from Construction Courses)

The students were asked to rate the importance of issues related to sustainable design and construction. Eight sustainability options were given, including 1) environmental sustainability, 2) societal sustainability, 3) economic sustainability, 4) energy sustainability, 5) water sustainability, 6) material choice sustainability, 7) zero-emission sustainability, and 8) lean zero-waste sustainability. From Figure 1, most of the students think that environmental sustainability (38 students, 57.58\%), energy sustainability (37 students, 56.06\%), and water sustainability (38 students, 56.57\%) are extremely important for sustainable design. Societal sustainability (30 students, $45.45 \%$ ) was rated more frequently as "very important" than as "extremely important". Material choice sustainability (11 students, 16.67\%), zero-emission sustainability (12 students, 18.18\%), and lean zero-waste sustainability (ten students, $15.15 \%$ ) were the three options most frequently rated as "moderately important". The results were similar between "slightly important" and "not at all important". From the data, we note that environmental sustainability received the highest average score, with the average scores of energy sustainability and water sustainability close to that of environmental sustainability.

A comparison between average overall scores and independent variables is shown in Figure 2 with an average score of 4.3. The average scores of having and not having work experience are the same as the overall score. The rankings by males and minorities were lower than the overall average. And the averages of female and non-minority participants were higher than the overall. Female respondents had the highest average score. Students also prioritized sustainability issues by ranking them. Table 2 shows the ranking of greatest future impact (top priority by 1 and bottom priority by 8 ). The Table also illustrates the ranking of the sustainability issues by male/female, minority/non-minority, and undergraduate/graduate students, and construction work experience/no work experiences. 


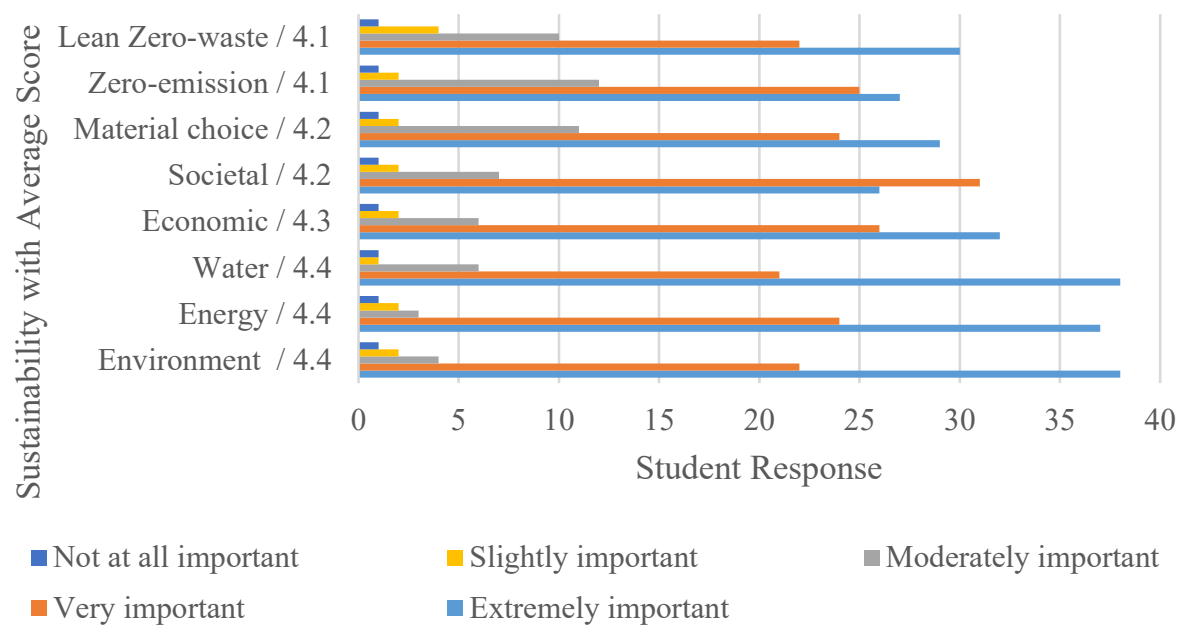

Figure 1: Important issues related to sustainability among students ( $5=$ extremely important, $1=$ not important $)$

Table 2: The Greatest Impact of Sustainability Score among student diversity

\begin{tabular}{|l|r|r|r|r|r|r|r|}
\hline & Overall & Male & Female & Minority & $\begin{array}{l}\text { Non- } \\
\text { minority }\end{array}$ & $\begin{array}{l}\text { Work } \\
\text { Experience }\end{array}$ & $\begin{array}{l}\text { No Work } \\
\text { Experience }\end{array}$ \\
\hline $\begin{array}{l}\text { Environmental } \\
\text { Sustainability }\end{array}$ & 1 & 1 & 1 & 1 & 1 & 1 & 1 \\
\hline $\begin{array}{l}\text { Societal } \\
\text { Sustainability }\end{array}$ & 2 & 2 & 5 & 2 & 2 & 2 & 2 \\
\hline $\begin{array}{l}\text { Economic } \\
\text { Sustainability }\end{array}$ & 3 & 4 & 2 & 3 & 3 & 3 & 3 \\
\hline $\begin{array}{l}\text { Energy } \\
\text { Sustainability }\end{array}$ & 4 & 3 & 8 & 3 & 5 & 4 & 5 \\
\hline $\begin{array}{l}\text { Water } \\
\text { Sustainability }\end{array}$ & 5 & 5 & 3 & 5 & 4 & 5 & 4 \\
\hline $\begin{array}{l}\text { Material choice } \\
\text { Sustainability }\end{array}$ & 6 & 6 & 6 & 6 & 6 & 6 & 7 \\
\hline $\begin{array}{l}\text { Zero-emission } \\
\text { Sustainability }\end{array}$ & 7 & 7 & 4 & 7 & 6 & 7 & 6 \\
\hline $\begin{array}{l}\text { Lean Zero-waste } \\
\text { Sustainability }\end{array}$ & 8 & 8 & 6 & 8 & 8 & 8 & 8 \\
\hline
\end{tabular}

Figure 3 shows information regarding the sources of student knowledge on sustainability. The data indicates that most of the students gained knowledge about sustainability from education, either high school $(10 \%)$ or college $(30 \%)$. Some got sustainability knowledge from mass media (total of $31 \%$ ) such as TV, radio, website, and social media. Also of note, some knowledge was not from education, but from work experience (7\%). On the other hand, there were also $11 \%-13 \%$ of students who said that they did not know about sustainability. 
Average Sustainability Score compare with Demography

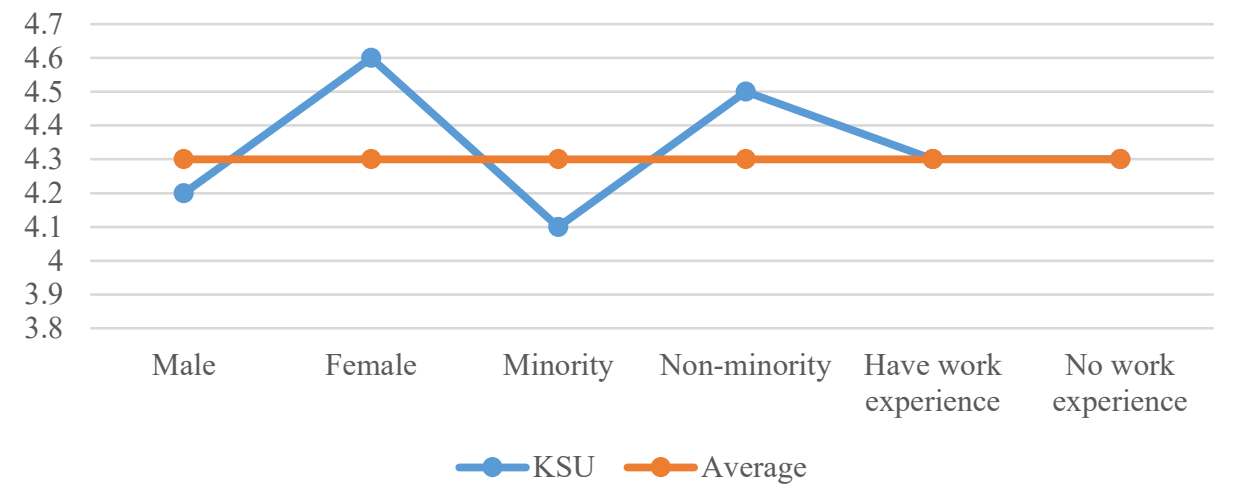

Figure 2: Average Sustainability Score Compare with the diversity of students

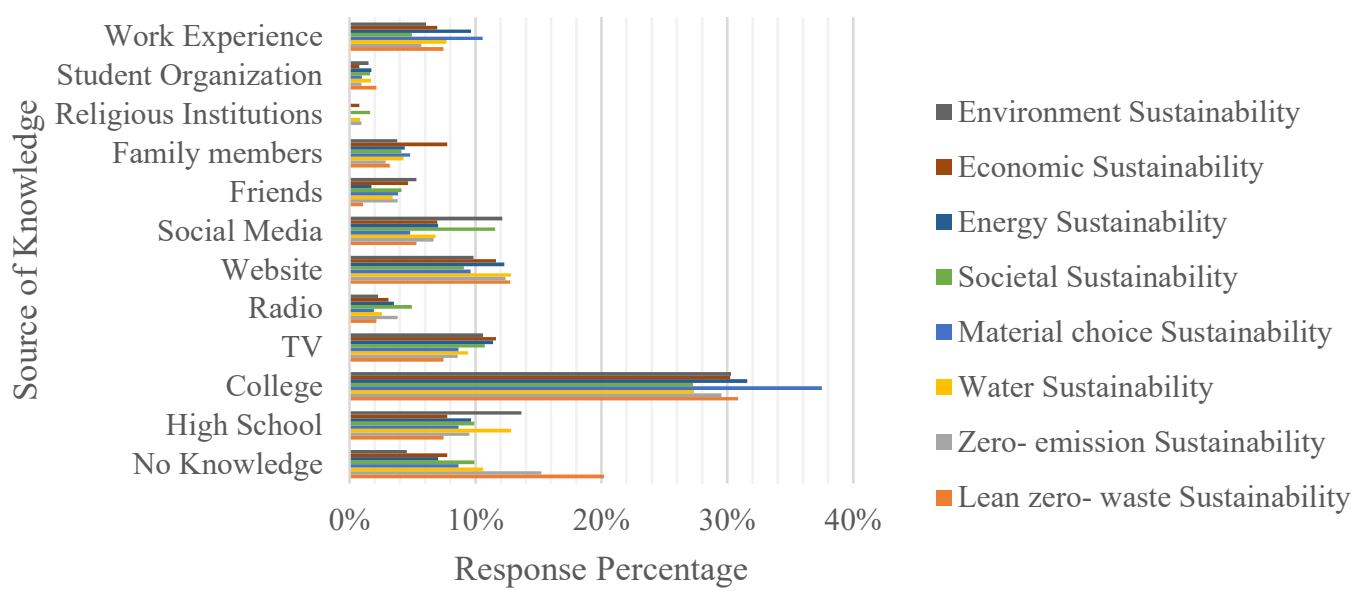

Figure 3: Source of Knowledge

Because a lot of students get their knowledge from education, it is important to study how education provided in their major informed their knowledge to practice sustainable design in the future. Of 72 participants, 60 responded to the question on sustainability education from the construction major. As shown in Figure 4a, 40 (66.67\%) of those 60 respondents indicated "yes" or "probably yes", that education provided in their major prepares them to practice sustainable design in the future. 16 (26.67\%) students feel that education "might" or "might not" prepare them, with four $(6.67 \%)$ students indicating that education "probably does not" help them. Also, one student points out that he/she learned about LEED certifications from the courses. LEED is a green building certification program used worldwide and in these 60 students, three (5\%) students already have LEED accreditation, while $43(71.67 \%)$ students do not have any LEED accreditation. On the other hand, 11 $(18.33 \%)$ students plan to get accredited in the future, and three $(5 \%)$ students are not interested in LEED. Figure $4 \mathrm{~b}$ shows sustainable education and LEED accreditation from student responses. Figure 5 shows construction management $(\mathrm{CM})$ courses that have a component of sustainability. 
This survey also asked students if they want to continue to pursue sustainable design and construction. $19(31.67 \%)$ students responded that they aspired to continue the study of sustainable design and construction after graduation. Over half of the students (51.67\%) think they do not know yet what they want for the future. Next, the survey asked students if they aspire to have a career related to sustainable design and construction. 17 students (28.33\%) said "yes" and 18 students (30\%) said "no". Also, 25 students $(41.67 \%)$ responded: "do not know". Figure 6 shows the aspiration of sustainable education and career. From these two questions, we realize that about half of the students do not know what they want to do after they graduate.

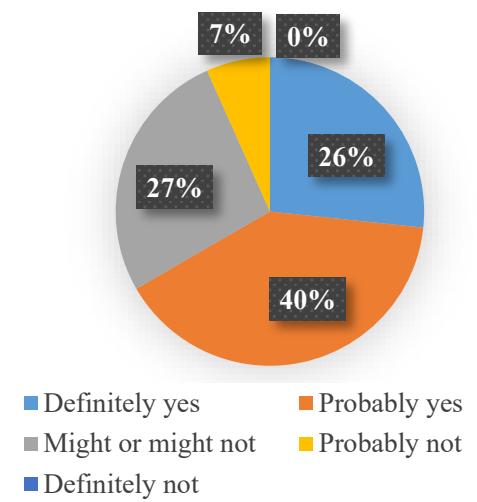

a) Sustainability Education from construction major

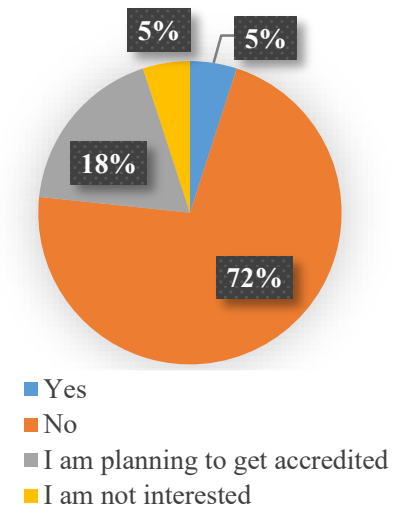

b) LEED accreditation

Figure 4: Sustainable Education and Accreditation

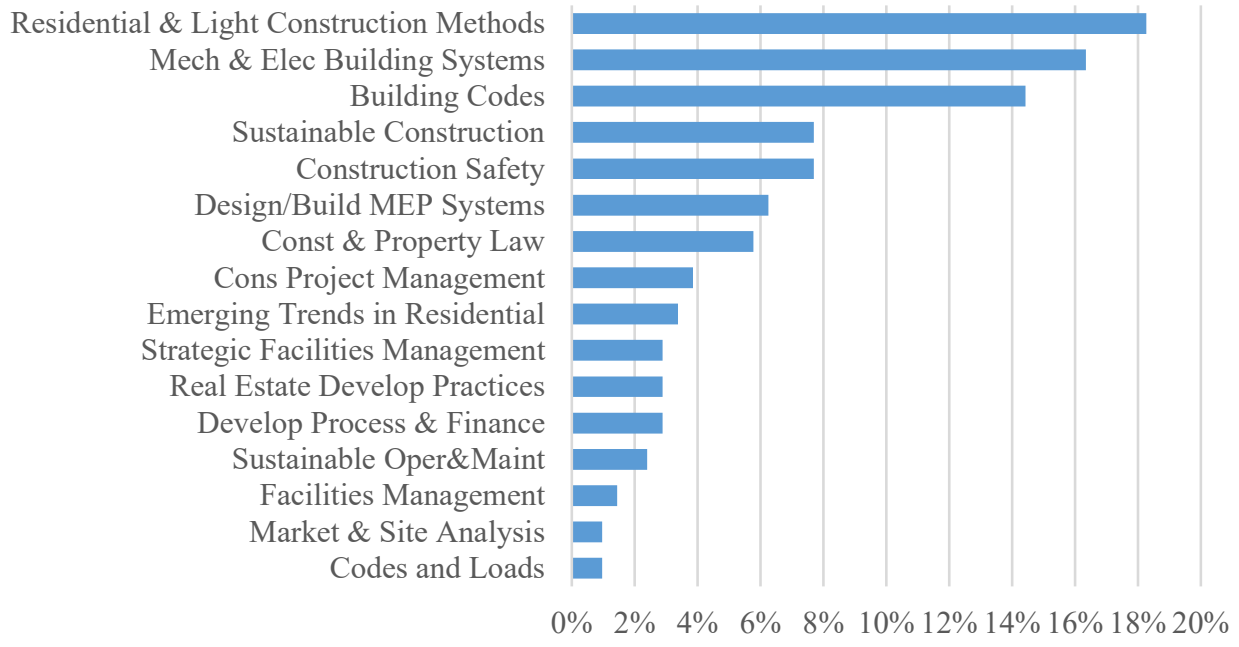

Figure 5: CM courses that have the component of sustainability 


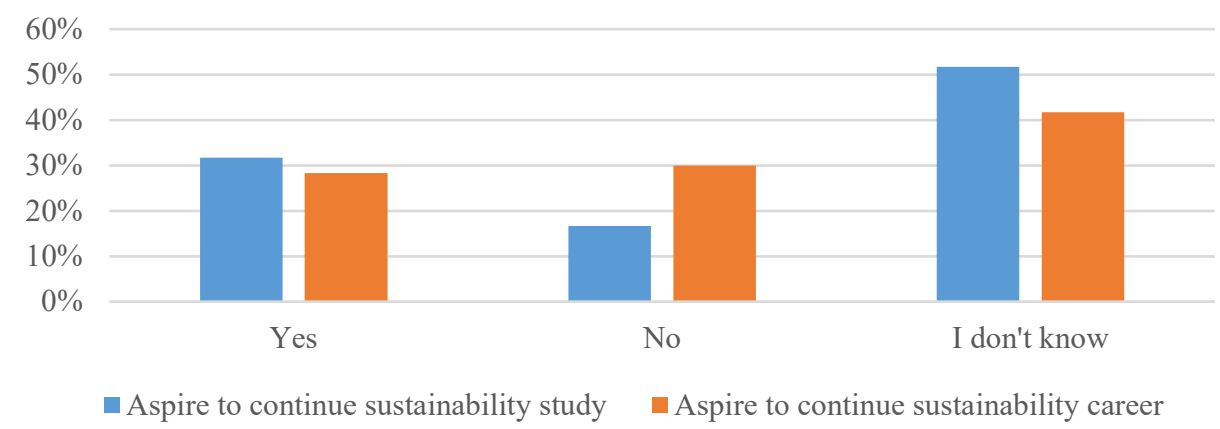

Figure 6: Aspiration of Sustainable Education and Career

\section{Conclusion}

In analyzing the given sustainability options of environmental sustainability, societal sustainability, economic sustainability, energy sustainability, water sustainability, material choice sustainability, zero-emission sustainability, and lean zero-waste sustainability, most of the students surveyed think water sustainability is "extremely important". There is the same number of students who think environmental sustainability is "extremely important" as water sustainability and students selected energy sustainability as the third choice for "extremely important" after water sustainability and environmental sustainability. Comparing the difference between male and female, minority or nonminority, and have work experience or not, it is found that most of the male students think environmental sustainability (31 students, 53.45\%) and water sustainability (31 students, 53.45\%) are the most important issues related to sustainable design and construction. There were also about 30 $(51.72 \%)$ male students who believe that energy sustainability is extremely important for sustainable design and construction. Different from males, female students think that environmental sustainability, energy sustainability, water sustainability, and lean zero-waste sustainability were “extremely important" for sustainable design and construction.

From the statistical data, both male and female students think environmental, energy, and water sustainability are the top three issues of importance for sustainable design and construction. Of additional note is that female students also think lean zero-waste sustainability is an "extremely important" issue related to sustainable design and construction. Minority students believe environmental sustainability is "extremely important" whereas non-minority students think energy and water sustainability are the "extremely important" issues. These three options are all the top three choices for minority and non-minority students alike. Students who had work experience selected environmental sustainability as the most important issue and students who had no work experience selected energy sustainability as the most important issue related to sustainable design and construction. Whether they had work experience or not, all the students indicated that water sustainability is the second most important issue for sustainable design and construction.

Analysis of the survey responses offers three key findings. First, the survey suggests that many students get their knowledge on sustainability primarily from higher education, so it is important for universities to offer some related courses about sustainable design and construction. However, for the top three courses perceived by this pool of students as including sustainability content - residential and light construction, mechanical \& electrical building systems, and building codes - the respondent percentage was merely $18.27 \%, 16.35 \%$, and $14.42 \%$, respectively. In this case, the construction management program needs more sustainability topics. Second, the responses show that over $40 \%$ of 
students surveyed have not yet decided if their future career path will include sustainable construction approaches, indicating that there is substantial room for degree programs to inform the decisionmaking process. Lastly, the study also found that the topic students most identified as having "no knowledge" of was lean zero-waste sustainability and that this same topic was ranked lowest in perceived future impact, suggesting a link between topics covered in courses and students' perception of the potential impact of those approaches. Future studies are recommended to learn more about how student perceptions change regarding knowledge gained on construction sustainability, how best to increase knowledge gained by students on these topics, and how to increase interest in future pursuit of sustainability knowledge.

\section{References}

Ahn, Y. H., Pearce, A. R., Wang, Y., \& Wang, G. (2013). Drivers and barriers of sustainable design and construction: The perception of green building experience. International Journal of Sustainable Building Technology and Urban Development, 4(1), 35-45.

Boardman, B. (2004). Starting on the road to sustainability: Environmentally sustainable buildings: challenges and policies. Building Research \& Information, 32(3), 264-268.

Haines, C. (2010). The role of the architect in sustainability education. The Journal of Sustainability Education.

Hassanpour, B., Alpar Atun, R., \& Ghaderi, S. (2017). From words to action: Incorporation of sustainability in architectural education. Sustainability, 9(10), 1790.

Humphries-Smith T. (2008) Sustainable design and the design curriculum. Journal of Design Research, Futures of Design Education Special Edition, 7 (3), 259-274.

Iyer-Raniga, U., Arcari, P., \& Wong, J. P. (2010, September). Education for sustainability in the built environment: what are students telling us? In 26th Annual ARCOM conference (pp. 1447- 1456).

Iyer-Raniga U., Andamon M.M.(2012). Sustainability Education in the Engineering and Built Environment Curriculum: The case for Asia-Pacific., ICERI2012 Proceedings, pp. 5190-5200. 19-21 November 2012, Madrid, Spain: IATED.

NAAB. 2012. Available online: http://www.naab.org/accreditation/2012_Procedures (accessed on 18 March 2016).

Sheehan, K. B. Email Survey Response Rates: A Review. Journal of Computer-Mediated Communication, 6(JCMC621), 2001 https://doi.org/10.1111/j.1083-6101.2001.tb00117.x

Tinkler A. \& Burt R. (2004). "Greening” the construction curriculum. International Journal of Construction Education and Research, 9 (2), 26-33

Wang, Y. (2009). Sustainability in construction education. Journal of professional issues in engineering education and practice, 135(1), 21-30.

Wu, W., and Luo, Y. (2016) 'Pedagogy and Assessment of Student Learning in Bim and Sustainable Design and Construction', Journal of Information Technology in Construction (ITcon), 21(21), pp. 218-232.

World Federation of Engineering Organizations (WFEO). (2006). "WFEO mission." http://www.wfeo.org/index.php?page=mission (Nov. 12, 2006).

World Green Building Council, 2017. About Green Building, What is Green Building? Online News.

Yüksek, 'I. The Evaluation of Architectural Education in the Scope of Sustainable Architecture. Procedia-Soc. Behav. Sci. 2013, 89, 496-508. 